\title{
СИНТЕЗ ХИРАЛЬНЫХ ПОЛИГЕТЕРОЦИКЛИЧЕСКИХ СОЕДИНЕНИЙ НА ОСНОВЕ МОНОТЕРПЕНОИДА ТРАНС-4-ГИДРОКСИМЕТИЛ-2-КАРЕНА
}

\author{
Н.С. Ли-Жуланов' , И.В. Ильина', А.Ю. Сидоренко², К.П. Волчо', \\ Н.Ф. Салахутдинов'
}

\author{
${ }^{1}$ Новосибирский Институт Органической Химии СО РАН, \\ 630090, Россия, Новосибирск, пр. Академика Лаврентьева, 9. \\ ${ }^{2}$ Институт Химии Новых Материалов НАН Беларуси, \\ 220141, Беларусь, Минск, ул. Франциска Скорины 36.
}

DOI: 10.19163/MedChemRussia2021-2021-159

E-mail: lizhulanov@mail.ru

Селективная модификация природных соединений - один из наиболее важных способов разработки и поиска новых биологически активных веществ различных структурных типов. Ранее нами было показано, что при взаимодействии транс-4-гидроксиметил-2-карена (вальтерола) с ароматическими альдегидами образуются гетероциклические соединения типа 1, ряд из которых обладает биологической активностью, например, продукт реакции вальтерола с изованилином обладает высокой цитотоксической активностью [1].

В настоящей работе мы изучили взаимодействие вальтерола с рядом 3,4,5-замещенных бензальдегидов и набором гетероароматических альдегидов в присутствии разнообразных гетерогенных катализаторов. В случае реакции с 3,4,5-замещенными бензальдегидами мы наблюдали образование в качестве основного продукта соединения с флуоренофурановой структурой 2, тогда как при взаимодействии с гетероароматическими альдегидами наблюдалось образование полициклических соединений 3, содержащих два остатка альдегида. Таким образом, полученные соединения новых структурных типов представляют большой интерес для изучения их биологических свойств.

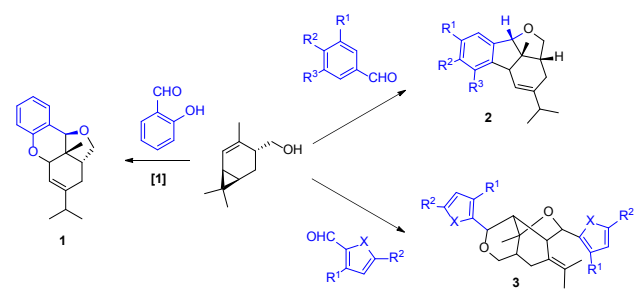

Работа выполнена при финансовой поддержке Российского фонда фундаментальных исследований (грант 20-53-00004 бел_а) и Белорусского республиканского фонда фундаментальных исследований (грант X20R-001).

\section{Литература}

[1] S.Yu. Kurbakova, I.V. Il'ina, O.S. Mikhalchenko, M.A. Pokrovsky, D.V. Korchagina, K. P. Volcho, A.G. Pokrovsky, N.F. Salakhutdinov, The short way to chiral compounds with hexahydrofluoreno[9,1-bc]furan framework: Synthesis and cytotoxic activity, Bioorg. Med. Chem., 2015, 23, 1472-1480. 